\title{
EFEFCT OF DIETARY SUPPLEMENTATION WITH HUMATE ON EGG PRODUCTION AND EGG SHELL QUALITY DURING THE LATE LAYING PERIOD OF LOCAL STRAIN HENS
}

\author{
R.A. Hassan
}

Animal Production Research Institute, Agricultural Research Center, Ministry of Agriculture, Egypt

\section{SUMMARY}

This study was designed to investigate the effect of humate inclusion into diet of hens during the late laying period on egg production traits and egg quality. Two hundreds of El-Salam strain hens $(n=200) 50$ wk of age were allocated to four treatment groups, namely $\mathrm{H}_{0}, \mathrm{H}_{1}, \mathrm{H}_{2}$ and $\mathrm{H}_{3}$. Control $\left(\mathrm{H}_{0}\right)$ hens were fed a basal diet, while, $\mathrm{H}_{1}, \mathrm{H}_{2}$ and $\mathrm{H}_{3}$ hens were fed the basal diet supplemented with 0.1, 0.25 and $0.4 \%$ humate, respectively. Active ingredients of humate were polymeric polyhydroxy acids (humic, fulvic, ulmic and humatomelanic acids). Egg production and egg weight were recorded daily and feed intake was evaluated biweekly. Also, a sample of 15 eggs from each group was collected randomly to determine egg quality every 28 days. Egg production and egg mass in the $H_{2}$ and $H_{3}$ were higher than $H_{0}$ and $H_{1}$ hens. Total feed intake in $\mathrm{H}_{3}$ and $\mathrm{H}_{2}$ groups were significantly higher $(P<0.05)$ than $H_{1}$ hens. Egg weight, feed conversion ratio and egg quality (egg yolk\%, egg albumen $\%$, yolk index $\%$, Haugh unit and egg shape index) were not affected by dietary humate. Egg shell quality values (shell \%, shell thickness, cracked egg \%, and shell ash \%) of $\mathrm{H}_{1}$ and $\mathrm{H}_{2}$ hens were higher than $\mathrm{H}_{3}$ hens. In conclusion, supplementation of humate at $0.25 \%$ during the late laying period could improve egg shell quality.

Keywords: Humate, feed additive, egg production, egg shell quality, Local chickens

\section{INTRODUCTION}

To enhance nutrient utilization, improve feed conversion efficiency, and maintain health status, inclusion of probiotics and humates in rations is preferable to antibiotics, primarily because they cause no harmful effects to consumers (Onifade et al., 1999). Humates, a part of fertilizers, are derived from plant matter decomposed by bacteria (Senn and Kingman, 1973) and contain humus, humic acid, fulvic acid, ulmic acid and some microelements (Stevenson, 1994). Previous studies with respect to humates have focused mainly on the growth of germinal tissue in seed. The attitude of using humates as feed additives in animal nutrition is new. At first, humate was used as a part of replacement therapy for digestive system disturbances such as malnutrition and diarrhea and to increase feed efficiency in calves, dogs and cats (Kuhnert et al., 1991).

Issued by The Egyptian Society of Animal Production 
Egg production and egg quality are the most important economic traits for layer farms. One of the most important factors affecting the profitability of egg production is the age-related decline in egg shell quality (Nys, 1999) due to reduction in mineral utilization and increase in egg shell surface as the hens aged. If eggs with poor shell quality pass through the system undetected, they can also constitute a risk to food safety. Therefore, control of the egg shell quality still of great consideration (Bain, 2005).

Since mineral premixes or feed additives can promote the utilization of minerals, they should be added to layers diets to improve egg shell quality. Humic substances (HS) that are complex mixtures of polyaromatic and heterocyclic chemicals with multiple carboxylic acid side chains (Klocking, 1994 and MacCarthy, 2001) might be one of these feed additives for enhancing egg production and egg shell quality. Indeed, Yoruk et al. (2004) reported that supplementation of humate into the diet at level of 0.1 and $0.2 \%$ during the late laying period increased egg production, improved feed efficiency and reduced mortality. Moreover, it has been reported that addition of humate into layer diets at a level of 30 and $60 \mathrm{mg} / \mathrm{kg}$ (Kucukersan et al., 2005), up to $0.3 \mathrm{~g} / \mathrm{Kg}$ ( Hayirli et al., 2005) or $2 \mathrm{~g} / \mathrm{Kg}$ (Kucukersan et al., 2004) can improve egg production, egg weight and feed efficiency. However, previous studies (Yoruk et al., 2004 and Hayirli et al., 2005) showed that egg shell quality parameters were not affected by dietary inclusion of humate layers .

These observations highlight that the importance of dietary humate supplementation may have critical consequence on egg production during laying period. On the other hand, due to the ability of humate to bind materials in certain environments and to release these materials under different environmental conditions (Shermer et al., 1998), dietary humate may prevent reduction in egg production and egg shell quality after peak laying period. Therefore, more information is still needed about the effect of humate on egg shell quality and egg production after peak period. The objective of this study was to investigate effect of adding humate a laying diet on egg production and egg quality during the late laying period.

\section{MATERIALS AND METHODS}

This study was carried out at Sakha Animal Production Research Station, Animal Production Research Institute, Agricultural Research Center, Ministry of Agriculture.

\section{Hens and Management:}

A total of 200 El-Salam strain 50- week old hens were used. They were randomly distributed into four groups each composed of 5 equal replicates and housed in 20 floor pens at 10 hens per pen under conventional conditions with access to feed and water ad libitum and photoperiod of 16 hours was maintained. Hens were fed on a layer diet (Table 1). This study lasted from $50^{\text {th }}$ to $62^{\text {nd }}$ weeks of age.

\section{Treatments and Experimental protocol:}

The experimental humate was supplemented to the basal diet of treatment groups at $0.0,0.1,0.25$ and $0.40 \%$. Biofarm ${ }^{\circledR}$ Dry, totally natural humate was purchased from Farmavet International Istnbul-Turkey. Each $\mathrm{kg}$ of humate contained $160 \mathrm{mg}$ polymeric polyhydroxy acid (humic, fulvic, ulmic and humatomelanic acids), 663.3 $\mathrm{SiO} 2$ and other minerals (Mn, $50 \mathrm{mg}$; Zn, $60 \mathrm{mg}$; Fe, $60 \mathrm{mg}$; $\mathrm{Cu}, 5 \mathrm{mg}$; Co, $0.2 \mathrm{mg}$; I, $1 \mathrm{mg}$; Se, $0.5 \mathrm{mg}$ and $\mathrm{Al}, \mathrm{Na}, \mathrm{K}, \mathrm{Mg}$ and $\mathrm{P}$ in trace amounts). 


\section{Measurements:}

Body weight at the beginning and the end of the experiment was individually recorded. Egg production, egg weight, cracked eggs and mortality were also recorded daily. Feed consumption was recorded weekly and feed efficiency was calculated. Egg quality measurements (egg shell, albumin and yolk weights) were measured using 15 eggs from each treatment group at the last 2 days of each month. Albumin, yolk and shell percentages, and Haugh units were also calculated. Yolk index percentage was calculated as yolk height divided by yolk diameter (Well, 1968). Exterior shell quality evaluation is based on shell thickness and shell ash. Shell ash was determined at $550^{\circ} \mathrm{C}$ for 6 hours after drying at room temperature for 3 days. Shell thickness was measured with a micrometer gauge from three (top, middle and bottom) parts of the shell after shell membrane was separated from the egg shell.

Table 1. Composition* and calculated analysis of the basal diet

\begin{tabular}{|c|c|}
\hline Ingredients & $\%$ \\
\hline Yellow corn & 64.0 \\
\hline Soybean meal (44\%) & 24.78 \\
\hline Wheat bran & 1.00 \\
\hline Di-calcium phosphate & 1.61 \\
\hline Limestone & 7.91 \\
\hline DL-Methionine & 0.10 \\
\hline Sodium chloride & 0.30 \\
\hline Vit. \& Min. Mixture ${ }^{* *}$ & 0.30 \\
\hline Total & 100.00 \\
\hline \multicolumn{2}{|l|}{ Calculated analysis: } \\
\hline Metabolizable energy $(\mathrm{kcal} / \mathrm{kg})$ & 2718 \\
\hline Crude protein $\%$ & 16.02 \\
\hline Crude fiber $\%$ & 3.46 \\
\hline Crude fat $\%$ & 2.96 \\
\hline Calcium \% & 3.34 \\
\hline Available phosphorus $\%$ & 0.42 \\
\hline Lysine $\%$ & 0.89 \\
\hline Methionine $\%$ & 0.39 \\
\hline Methionine + Cystine $\%$ & 0.66 \\
\hline \multicolumn{2}{|c|}{$\begin{array}{l}\text { * As recommendation of Animal Production Research Institute, Agric. Res. Center } \\
\text { ** Supplied per kg diet: Vit. A., } 10000 \mathrm{IU} \text {; Vit. D3, } 2000 \mathrm{IU} \text {; Vit. E } 10 \mathrm{mg} \text {; Vit. K3, } 1 \mathrm{mg} \\
\text { Vit. B1, } 1 \mathrm{mg} \text {; Vit. B2, } 5 \mathrm{mg} \text {; Vit. B6, } 1.5 \mathrm{mg} \text {; Vit. B12, } 10 \mathrm{mg} \text {; Niacin, } 30 \mathrm{mg} \text {; Pantothenic } \\
\text { acid, } 10 \mathrm{mg} \text {; Folic acid, } 1 \mathrm{mg} \text {; Biotin, } 50 \mathrm{mg} \text {; Choline, } 260 \mathrm{mg} \text {; Copper, } 4 \mathrm{mg} \text {; Iron, } 30 \mathrm{mg} \\
\text { Manganese, } 60 \mathrm{mg} \text {; Zinc, } 50 \mathrm{mg} \text {; Iodine, } 1.3 \mathrm{mg} \text {; Selenium, } 0.15 \mathrm{mg} \text {; Cobalt, } 0.1 \mathrm{mg} \text {. }\end{array}$} \\
\hline
\end{tabular}

All eggs in the experiment were visually checked for cracks and breakage under artificial lighting.

Statistical analysis:

Data were statistically analyzed using one way ANOVA (SAS, 1994). Before analysis, all percentages were subjected to logarithmic or arcsine values transformation $(\log 10 \mathrm{x}+1)$ to approximate normal distribution. Significant differences among treatment means $(\mathrm{P} \leq 0.05)$ were separated by Duncan's new multiple range test (Duncan, 1955). 


\section{RESULTS AND DISCUSSION}

Results in Table 2 indicate that humate supplementation had insignificant effect on final live body weight. These results are in agreement with those reported by Kocabagli et al. (2002) and Karaoglu et al. (2004) who indicated that no significant effect on body weight and daily weight gain of broiler chickens fed diet with humate compared with the control group. While, Shermer et al. (1998) showed that the humic acid stabilizes the intestinal microflora and thus ensures an improved utilization of nutrients in animal feed, this leads to an increase in the live body weight of laying hens.

Table 2. Effect of humate supplementation on productive performance of ElSalam laying hens

\begin{tabular}{lccccc}
\hline \multirow{2}{*}{ Items } & \multirow{2}{*}{ Control } & \multicolumn{3}{c}{ Humate level, \% } & \multirow{2}{*}{ SEM* } \\
\cline { 3 - 5 } & & 0.10 & 0.25 & 0.40 & \\
\hline Initial body weight, g & 1700 & 1710 & 1705 & 1700 & 23.14 \\
Final body weight, g & 1750 & 1750 & 1767 & 1760 & 25.33 \\
Egg laying rate (hen\day), \% & $45.24^{\mathrm{b}}$ & $46.43^{\mathrm{b}}$ & $47.62^{\mathrm{ab}}$ & $48.80^{\mathrm{a}}$ & 1.46 \\
Egg weight, g & 52.4 & 52.0 & 52.5 & 52.4 & 0.8 \\
Egg mass, g/bird/d & 23.70 & 24.14 & 25.00 & 25.59 & 0.62 \\
Feed intake, g/bird/d & $92.5^{\mathrm{b}}$ & $91.60^{\mathrm{b}}$ & $96.00^{\mathrm{ab}}$ & $100.0^{\mathrm{a}}$ & 1.51 \\
Feed conversion, g feed: g egg & 3.90 & 3.79 & 3.84 & 3.90 & 0.42 \\
Mortality number & 1 & 2 & 1 & 2 & -- \\
\hline a,b,c & & 2 & 1 & 2
\end{tabular}

${ }^{a, b},{ }^{c}$ Mean in the same row with different letters are differ significantly at $\mathrm{P} \leq 0.05$.

*SEM: Standard error of the mean.

The egg production, egg weight, egg mass, feed intake and feed conversion ratio values of treatment groups are shown in Table (2). Total egg production (laying percent,\%) in $\mathrm{H}_{2}$ and $\mathrm{H}_{3}$ treatment groups were higher (by 5.3 and $7.8 \%$ ) than control group $(\mathrm{P}<0.05)$. The egg production of $\mathrm{H}_{1}$ group was higher than control, although the augmentation did not reach statistical significant. Therefore, $\mathrm{H}_{2}$ and $\mathrm{H}_{3}$ groups were higher in terms of egg mass than $\mathrm{H}_{0}$ and $\mathrm{H}_{1}$ groups $(\mathrm{P}<0.05)$. In Similar studies, Kucukersan et al. (2004) and Yoruk et al. (2004) found that supplementation of humate in layer diets at 0.1 and $0.2 \%$ for 75 days during the late laying period caused egg production increase compared to control group. Contrary to this, Ceylan et al. (2003) found no effect of dry humate on egg production. Feed consumption of $\mathrm{H}_{2}$ and $\mathrm{H}_{3}$ groups were higher than those of $\mathrm{H}_{1}$ group $(\mathrm{P}<0.05)$. This results agree with those of Ergin et al. (2009) who reported that feed intake was significantly higher at $90 \mathrm{ppm}$ humate supplementation compared with $30 \mathrm{ppm}$ humate for hens after peak laying period. Yoruk et al. (2004) found that humate with concentration of 0.1 and $0.2 \%$ had no significant effect on feed intake in late stage of laying. However, Kucukersan et al. (2005) showed that the average daily feed consumption of hen fed diets with humic acid was significantly $(\mathrm{P} \leq 0.05)$ decreased compared with the control group.

There were no statistical significant differences among the control and other treatment groups in term of FCR. In a previous work by Ceylan et al. (2003) they did not find any effect of dry humate on FCR during the laying period. However, 
Kucukersan et al. (2004) and Yoruk et al. (2004) reported a significant improvement of FCR in the early laying period.

In this study, there was no effect of humate on egg weight (Table 2). These result agreed with the results of Ceylan et al. (2004) and Yoruk et al. (2004).

The increase in the egg production and egg mass in $\mathrm{H}_{2}$ and $\mathrm{H}_{3}$ treatment groups may be due to the increase in feed intake of birds compared with $\mathrm{H}_{0}$ group.

These results may indicate that higher doses of humate are more effective than lower doses to increase feed intake. Therefore, decrease feed intake in $\mathrm{H}_{1}$ group compared with $\mathrm{H}_{2}$ and $\mathrm{H}_{3}$ treatment groups without improving feed efficiency was obtained which may be due to the detrimental effect of high humate on absorption of some nutrients and changes in metabolic profile.

Although the egg production of $\mathrm{H}_{1}, \mathrm{H}_{2}$ and $\mathrm{H}_{3}$ groups was similar, the fact that a lower feed intake in $\mathrm{H}_{1}$ group compared with $\mathrm{H}_{2}$ and $\mathrm{H}_{3}$ treatment groups may confirm that the effect of $\mathrm{H}_{2}$ and $\mathrm{H}_{3}$ on absorption of some nutrients and changes of metabolic profile was detrimental Stackhouse and Benson (1989) and Herzig et al. 1994). Hayirli et al. (2005) noted that changes in metabolic profile due to humate supplementation may be related to alteration in partitioning of nutrient metabolism. Moreover, some trace elements in humate may act as co-factor and consequently, increase the activity of several enzymes for digestion and utilization of nutrients (Hayirili et al., 2005). Such a beneficial effect of either low or high level of humate on the feed efficiency was not observed.

Streling et al. (2003) observed a positive correlation of feed intake with feed efficiency and egg mass. It may be understood that when feed intake was, therefore, evaluated together with egg production, egg weight and egg mass, feed efficiency did not differ among the groups.

Mortality for hens fed the control diet was not different from that for hens fed humate diets. There was also no effect of increasing the level of supplemental humate on mortality, (Table 2). Autopsy findings revealed that deaths were related to noninfectious causes. Little is known about the mechanism by which humate supplementation enhances the life span and improves production efficiency. However, available data consistently suggest that humate supplementation may benefit poultry production. Pukhova et al. (1987) reported that supplementation of $\mathrm{Na}$ humate in rats exposed to lethal doses of radioactivity increased the life span. In similar studies, it was shown that after high doses, supplemental humate alleviates toxicity of $\mathrm{Cr}$ in fish (Stackhouse and Benson, 1989) and Cd in chickens (Herzig et $a l ., 1994)$ by reducing deposition of toxic metals in organs

\section{Egg quality:}

According to the results in Table 3, there were no effects of the experimental diets on shape index and yolk index. The results of Yoruk et al. (2004); Kucukersan et al. (2005) and Wang et al. (2007) support our findings regarding that there were no significant effects of humic acid supplementation on the studied egg quality traits. However, egg shell ash significantly increased $(\mathrm{P}<0.05)$ in by $\mathrm{H}_{1}$ and $\mathrm{H}_{2}$ compared with $\mathrm{H}_{0}$ and $\mathrm{H}_{3}$ groups (Table 3). This result agree with that of Eren et al. (2000) who reported that shell ash increased by liquid humate addition to drinking water at different laying periods.

Cracked egg ratio was markedly decreased $(\mathrm{P}<0.05)$ by humate supplementation in $\mathrm{H}_{1}$ and $\mathrm{H}_{2}$ (Table 3 ) compared with $\mathrm{H}_{3}$. Up to our knowledge, effect of humate 
on cracked egg ratio has not been investigated in any previous study. Only a related study by Gren et al. (2000) reported that dry humate supplementation to feed enhanced serum $\mathrm{Na}, \mathrm{K}$ and tibia bone ash levels in broilers.

Table 3. Effect of humate supplementation on egg quality of Elsalam laying hens

\begin{tabular}{|c|c|c|c|c|c|}
\hline \multirow[b]{2}{*}{ Items } & \multirow[b]{2}{*}{ Control } & \multicolumn{3}{|c|}{ Humate level, \% } & \multirow[b]{2}{*}{ SEM* } \\
\hline & & 0.10 & 0.25 & 0.40 & \\
\hline Egg yolk, \% & 30.32 & 30.12 & 30.47 & 30.16 & 0.66 \\
\hline Egg albumin, \% & 56.25 & 55.26 & 55.24 & 57.24 & 1.02 \\
\hline Yolk index, \% & 48.60 & 48.00 & 47.60 & 48.00 & 0.19 \\
\hline Haugh units & 78.75 & 78.54 & 79.25 & 78.52 & 2.62 \\
\hline Egg shape index & 74.55 & 75.08 & 75.98 & 75.90 & 0.87 \\
\hline Egg shell, \% & $13.83^{\mathrm{b}}$ & $14.28^{\mathrm{a}}$ & $14.72^{\mathrm{a}}$ & $13.53^{\mathrm{b}}$ & 0.53 \\
\hline Shell thickness, $\mathrm{mm}$ & $0.331^{\mathrm{b}}$ & $0.345^{\mathrm{ab}}$ & $0.356^{\mathrm{a}}$ & $0.321^{\mathrm{b}}$ & 0.007 \\
\hline Cracked egg, \% & $5.45^{\mathrm{a}}$ & $4.86^{\mathrm{b}}$ & $3.80^{\mathrm{c}}$ & $4.50^{\mathrm{b}}$ & 0.23 \\
\hline Egg shell ash, \% & $96.90^{\mathrm{b}}$ & $97.00^{\mathrm{a}}$ & $97.17^{\mathrm{a}}$ & $96.95^{\mathrm{b}}$ & 1.23 \\
\hline
\end{tabular}

${ }^{a, b, c}$ Mean in the same row with different letters are differ significantly at $\mathrm{P} \leq 0.05$.

*SEM: Standard error of the mean.

An earlier report by Chen and Balnave (2001) suggested that carbonic anhydrase played an important role in egg shell formation and showed optimal activity in slightly alkaline medium. This study concluded that humate might have improved egg shell calcification by increasing $\mathrm{Na}$ and $\mathrm{K}$ levels, or causing other cation-anion changes. Although not well known yet, these types of metabolic events in the body may be one reason to positive effect on cracked egg ratio.

An increase in egg shell thickness by supplementation of 0.1 and $0.25 \%$ humate compared to $0.4 \%$ humate supported the idea that high level of humic acid in diet decreased $\mathrm{Ca}$ and $\mathrm{P}$ contents of blood compared to control or low level of humic acid (Rath et al., 2006). Moreover, the increase in egg shell quality at supplementation of 0.1 and $0.25 \%$ humate indicated that the low level of humate increased the cell wall permeability or absorption of nutrients. As previously known, increased permeability allowed easier transfer of minerals from the blood to the bone and cells (Enviromate, 2002). Decreased egg shell thickness in the $0.4 \%$ humate group $\left(\mathrm{H}_{3}\right)$ compared to 0.1 or $0.25 \%$ humate treatment groups $\left(\mathrm{H}_{1}\right.$ and $\left.\mathrm{H}_{2}\right)$ may be attributed to enhanced egg mass and decrease in the egg shell thickness in this groups (Lin et al., 2004). This situation may also be related to the antagonism between minerals or other nutrients in humate and in basal diet, although the antagonism and synergism were not determined in the present study. However, the high level of humate decreases absorption of $\mathrm{Ca}, \mathrm{Mg}, \mathrm{Fe}$ and $\mathrm{P}$. Rath et al. (2006) reported that this may be due to a metal chelating effect of humic acid which is affected by large number of carboxylic acid side chains (Klocking, 1994). Also, Grimes et al. (2004) reported that organic mineral complexes could increase availability compared with inorganic sources.

Reduced egg shell thickness in the $\mathrm{H}_{3}$ group can also be explained by the reduction in the absorption of $\mathrm{P}$ by high level of humic acid (Rath et al., 2006) because the ratio of $\mathrm{Ca}$ to $\mathrm{P}$ are important factor as the primary determined for calcification of egg shell. 
The improved egg shell quality in the $\mathrm{H}_{1}$ and $\mathrm{H}_{2}$ treatment groups, despite the low feed intake, may be related to beneficial effect of low level of humate on absorption of nutrients such as $\mathrm{Ca}$ and $\mathrm{P}$ and/or changes in metabolic profile of these nutrients. The underlying mechanisms responsible for altered absorption of some nutrients and/or metabolic profile of these nutrients subsequent to the egg quality parameter described here remain unclear. However, the observation of of Rath et al. (2006) indicates that the nutritional properties of humic acid, stated above, particularly depend on it's a supplementation level into broiler diet.

The current study indicated that egg shell quality measured by shell ash, cracked egg ratio and egg shell thickness was more sensitive to supplemental humate than egg production or other egg quality criteria. Therefore, the low level of humate supplementation $(0.25 \%)$ during late laying period improve egg shell quality but not egg production and feed efficiency.

\section{REFERENCES}

Bain M.M., 2005. Recent advances in the assessment of eggshell quality and their future application. World's Poultry Science Journal, 61: 268-277.

Ceylan N., I. Ciftci, Z. Kahraman and C. Mizrak, 2003. Yumurta tavugu yemlerinde humat bilesikler (farmagulator dry plus) kullanımının performans, yumurta kalitesi ve bagırsak mikroflorası uzerine etkileri. II. Ulusal Hayvan Besleme Kongresi, 18-20 Eylul, Konya, Turkiye.(In Turkish)

Chen J. and D. Balnave, 2001. The influence of drinking water containing sodium chloride on performance and eggshell quality of a modern, colored layer strain. Poult. Sci., 80: 91-94.

Duncan D.B., 1955. Multiple Ranged and Multiple F-tests. Biometrics 11: 1-42.

Enviromate T.M., 2002. Effects of humic acid on animals and humans (literature review and current research). Enviromate Inc. 8571 Boat Club Road, Forth Worth, Texas 76179. http://www.envir- omateinc.com.

Eren M., G. Deniz, S.S. Gezen and I.I.Turkmen, 2000. Broyler yemlerine katilan humatlarin besi performans, serum mineral konsantrasyonu ve kemik kuluuzerine etkileri. Ankara Univ. Vet. Fak. Derg. 47:255-263.(In Turkish)

Ergin O., I. Coskun, N. Ocak and G. Erener, 2009. Effects of dietary humic substances on egg production and egg shell quality of hens after peak laying period. African Journal of Biotechnology, Vol. 8 (6), pp. 1155-1159.

Grimes J.L., S. Noll, J. Brannon, J.L. Godwin, J.C. Smith and R.D. Rowland, 2004. Effect of a chelated calcium proteinate dietary supplement on the reproductive performance of large white turkey breeder hens. J. Appl. Poult. Res., 13: 639-649.

Hayirli A., N. Esenbuga, M. Macit, E. Lacin, M. Karaoglu, H. Karaca and L. Yildiz, 2005. Nutrition practice to alleviate the adverse effects of stress on laying performance, metabolic profile, and egg quality in peak producing hens: I. the humate supplementation. Asian-Austr. J. Anim. Sci., 18: 1310-1319.

Herzig I., J. Hampl, H. Docekalova, B. P1'sarı'kova' and J.V. Vlcek, 1994. The effect of sodium huminate on cadmium deposition in the organs of chickens. Vet. Med. (Praha), 39:175-185.

Klocking R., 1994. In Humic Substances in Global Environment: Implications for Human Health. T. Senesi and T. M. Miano, ed., Elsevier, Amsterdam, The Netherlands. 
Kucukersan S., K. Kucukersan, E. Goncuoglu and T. Sahin, 2004. The effects of dietary humate supplementation on laying hen egg production and egg quality. Indian Vet. J., 81: 674-678.

Kucukersan S., K. Kucukersan, I. Colpan, E. Goncuoglu, Z. Reisli and D. Yesilbag, 2005. The effects of humic acid on egg production and egg traits of laying hen. Vet. Med., 50: 406-410.

Kuhnert V.M., K.P. Bartels, S. Kroll and N. Lange, 1991. Huminsau“ rehaltige tierarzneimittel in therapie and prophylaxe bei gastrointestinalen erkrankungen von hund und katze. Monatshefte Vet. 46:4-8.

Lin Y.F., S.C. Chang and A.L. Hsu, 2004. Effects of supplemental vitamin E during the laying period on the reproductive performance Taiwan native chickens. Br. Poultry Sci., 45: 807-814.

MacCarthy P., 2001. The principles of humic substances. Soil Sci. 166:738-751.

Nys Y. 1999. Nutritional factors affecting egg shell quality. Cyech J. Anima. Sci., 44: 135-143.

Onifade A.A., A.A. Odunsi, G.M. Babatunde, B.R. Olorede and E. Muma, 1999. Comparison of the supplemental effects of Saccharomyces cerevisiae and antibiotics in low-protein and high-fiber diets fed to broiler chicken. Arch. Anim. Nutr., 52:29-39.

Rath N.C., W.E. Huff and G.R. Huff, 2006. Effects of Humic Acid on Broiler Chickens. Poultry Science, 85:410-414.

Pukhova G.G., N.A. Druzhina, L.M. Stepchenko and E.E. Chebotarev, 1987. Effect of sodium humate on animals irradiated with lethal doses. Radiobiologiia 27:650 653.

SAS Institute, 1994. SAS/STAT User's Guide: Statistics Ver. 6.04 fourth Edition. SAS Institute Inc., Cary, NC., USA.

Senn T.L. and A.R. Kingman, 1973. A Review of Humus and HumicAcids. Research Series Report No: 145, South Carolina Agricultural Experiment Station, Clemson, SC.

Shermer C.L., K.G. Maciorowski, C.A. Bailey, F.M. Byers and S. Ricke, 1998. Caecal metabolites and microbial populations in chickens consuming diets containing amined humate compound. J. Sci. Food Agric. 77:479-486.

Stackhouse R.A. and W.H. Benson, 1989. The effect of humic acid on the toxicity and bioavailability of trivalent chromium. Ecotoxicol. Environ. Safety, 17:105111.

Sterling K.G., D.D. Bell, G.M. Pesti and S.E. Aggrey, 2003. Relationship among strain, performance, and environmental temperature in commercial laying hens. J. Appl. Poult. Res., 12: 85-91.

Stevenson F.J., 1994. Humus Chemistry-Genesis, Composition, Reactions. John Wiley and Sons, New York, NY.

Yoruk M.A., M. Gul, A. Hayirli and M. Macit, 2004. The effects of supplementation of humate and probiotic on egg production and quality parameters during the late laying period in hens. Poult. Sci., 83:84-88. 
تأثير إضافة الهيومات فى العليقة على إنتاج البيض وجودة القشرة خلال فترة الإتتاج المتأخرة فى سلالة من الاجاج المحلى فلى العلى

\section{رضا على حسن}

قسم بحوث تغذية الدواجن، معطج بحوث الإنتاج الحيوانس، وزارة الزراعة، الجبيزة، مصر

صُمعت هذه الدراسة لدراسة تأثير أضافة الهيومات الى علائق الدجاج البياض خلال فترة الإنتاج

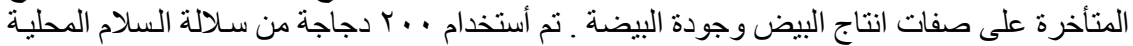

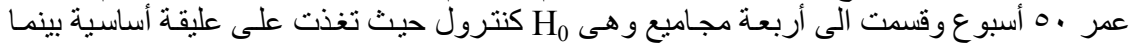
الجـاميع

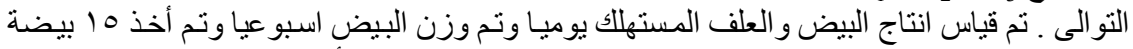

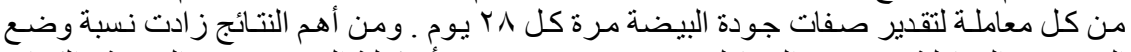
البيض فى المعاملة $\mathrm{H}_{3}$ عن المعاملتين

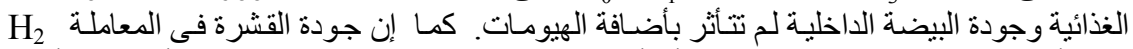

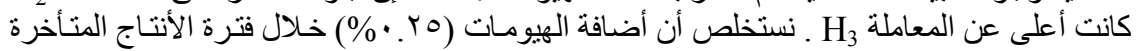

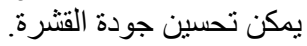

